\title{
Social Competencies for Pre-professional Socialization of the Student's Personality in the Context of Sustainable Development
}

\author{
Galina Trubina* \\ Ural State University of Economics, 620000 Yekaterinburg, Russia
}

\begin{abstract}
Modern schools continue to emphasize the nurturing of a socially oriented student, which should contribute to social maturity. As a consequence, there is a need to focus education on the development of a specific personality of the student, coordinated with the needs of society, the environment. The aim of the article is to develop and substantiate social competencies in education, which are a prerequisite for the successful socialization of students. The description of social competencies of a student's personality is based on the analysis, systematization, and generalization of scientific experience on the research problem. The article introduces the concept of socialization, presents social competencies, characterizes them, and shows specificity and behavioral indicators of social competencies. The author substantiates the relevance of using new social competencies, shows their features, which are formed not only in the interests of the student, his personal meanings but also in the interests of social development, which results in self-development, personal fulfillment in life, taking into account the features of society functioning at a certain period of its development. The educational environment provides motivation for learning and working activities, the ability to adapt to new socio-economic conditions. The author identifies social competencies that contribute to the successful socialization of students in the learning process, which can be used in the practical activities of educational institutions under the conditions of educational transformation.
\end{abstract}

\section{Introduction}

Nowadays, education is ahead of its time, adjusting its goals and objectives to the constantly changing world picture, the processes of globalization, the interdependence of economies of different countries, international developments, and the digitalization of society. This is reflected in the state documents defining the guidelines for the development of Russian education, which point to the need for personal socialization. The practice of life shows that there are problems related to the socialization of people in society.

In the conditions that resulted from this year's pandemic, many people lost jobs or closed small businesses. The forced long-term isolation as a litmus test revealed the level of socialization of the population. According to data from the Center for Labor Research and

\footnotetext{
${ }^{*}$ Corresponding author: gft@e-tagil.ru
} 
the Directorate for Expert Analytical Work of the National Research University Higher School of Economics, after the end of the "self-isolation regime", almost $10 \%$ of citizens lost their jobs, $40 \%$ saw their wages decrease, family members of $30 \%$ of respondents lost their jobs, $20 \%$ of Russians lost their bonuses, premiums, and privileges, and about $7 \%$ reported wage delays. The fall in wages and salaries affected construction, trade, services, $75 \%$ of self-employed, and $48 \%$ of those employed in medium and large enterprises to a greater extent. The pandemic in 2019 showed very clearly how the Russians showed themselves in this period. This adapted, realized their opportunities with regard to work, family, immediate environment, manifested their psycho-emotional state, i.e. in general, it became clear what the level of socialization of the individual was. Many people in this period revealed certain problems in the aspect of socialization, i.e. part of the population manifested such qualities as confusion, apathy, lack of tolerance in relation to the immediate environment, inability to adequately apply their social experience in the new changed conditions. This aspect clearly showed that somewhere in childhood, adolescence, social institutions, families, schools, and others have not been productive enough to form important social competencies for life.

\section{Literature Review}

The problem of personality socialization is a variable value, and will always be distinguished by the growing interest in it from scientists, sociologists, educators, didacticians, and the public. The institution of education will take one of the leading places in socialization. The upbringing of a socially-oriented personality through the institute of education is established in documents such as "National Doctrine of Education in the Russian Federation until 2025" [10], "Federal Target Program for the Development of Education for 2016 - 2020" [13], Federal Law dated December 29, 2012, No. 273-FZ "On Education in the Russian Federation" [14], etc. where it is also emphasized that a school graduate should be conscious of his activities, comprehend social responsibility as a value, have deep confidence that the goals, actions, and deeds will benefit him and other people, have a creative worldview and high culture.

At the same time, the strategic priority of state youth policy is to create conditions for the formation of a harmonious, constantly improving, erudite, competitive, not indifferent, having a strong moral core personality capable of adapting to changing conditions, receptive to new creative ideas, making independent decisions aimed at improving the well-being of the country, people and their families[7]. Here, the leading role in the socialization of young people is assigned to the educational system. In accordance with this, Russian education should be proactive, take on the role of tutor and coordinator of the impact on young people of the surrounding factors, determining the course of their preparation for life and work in a constantly changing environment, contribute to the development of human potential, to the solution of the most significant and acute social problems. Then pre-professional socialization in the process of schooling (preparatory stage to real life and work) will be one of the most important stages in the life of any person, which must be planned and managed. Innovative programs and technologies of professional socialization of schoolchildren at the stage of pre-profile training are already becoming a pedagogical reality today (I.V. Bestuzhev-Lada, A.K. Vaganov, A.E. Klimov, I.V. Nikishina, T.G. Novikova, S.N. Chistyakova, etc.), which occupies a significant place in the formation of professional and life career in school-age and is designed to promote 1) self-determination of high school students in choosing the profile directions of future education, 2) formation of adequate selfassessment of themselves in the profession, and 3) building a trajectory of further professional development.

But despite the society's need for socially active members with a stable personally significant position, navigating the complex modern socio-economic and political situation, 
the efforts of individual educators and scientists, the system of secondary general education is not fully created conditions conducive to the successful socialization of students and professional self-determination.

Studies show that many school students do not have a sufficient level of knowledge, skills in the choice of future profession, and their professional choice is poorly correlated with the needs of the regional economy and with their own capabilities. According to the survey on professional intentions of students in 8-11 grades of general educational organizations in the Ural region (9536 people, 2012-2018): the most popular spheres of future professional activity of school students in different years chose management (11-38\%), medicine (11$23 \%)$, education (10-22\%), art (10-18\%), transport (8-38\%), trade (6-24\%), communication (4-21\%), military business (2-12\%), which does not correspond to the needs of the industrial region in quality-quantitative characteristics of specialist training. Thus, pre-professional socialization focused on adequate self-determination of school children should be systematic and cover all subjects studied and form certain pre-professional competencies.

Despite the fact that the interest in studying socialization, self-determination of students as one of the stages of personality formation has recently increased (S.G. Vyatkin, E.E. Gornostaeva, T.V. Drobysheva, N.E. Skripova, A.V. Strelkova), the problem of training motivated, highly qualified specialists in the labor market in the ever-expanding professional sphere, still remains unsolved. According to statistics from the Russian Academy of National Economy and Public Administration, only 37 percent of university and college graduates work in their specialty. Thus, the problem of professional self-determination and preprofessional socialization of students is becoming extremely relevant for society, pedagogical science, and pedagogical practice.

In this regard, we consider methodologically relevant the idea of educating students with a certain kind of social competencies, which will allow forming and activating the personal and social potential of students in conditions of almost constant and dynamic transformation of society. Many foreign education systems are switching to the principles of social responsibility [2], [3], [4], [5] due to the fact that they see the problems that modern society faces, where there is an insufficient level of socialization of the population. This issue has received much attention from various scientists, but the ideas in the aspect of personality socialization, education of socially-oriented competencies are of constant interest and can be transformed by the changing socio-economic conditions of people's life.

Accordingly, this work relies on the pedagogical aspect of socialization (B.M. Bim-Bad, A.R. Demchenko, G.A. Kostetskaya, A.V. Mudrik, V.A. Slastenin, etc.); theory of personal professional self-determination (E.F. Zeer, E.A. Klimov); theory of personal competencies (A.V. Khutorskoy, I.A. Zimnaya, V.N. Kunitsina, A.I. Subetto, L.I. Bozhovich, D.I. Feldstein).

\section{Materials}

Education policy in Russia for the period up to 2030 will be implemented in accordance with the Concept of long-term socio-economic development of the Russian Federation, the tasks set by the President of the Russian Federation V.V. Putin in Decree No. 599 of May 7, 2012 "On Measures to Implement State Policy in Education and Science"[12], and Decree No. 597 "On Measures to Implement State Social Policy"[11]. In the framework of the state program, it is planned to provide funding for the development of vocational education, general and additional education for children; accessibility, quality of education; which will affect the socialization of young people as future participants in the labor market. According to the foundations of the state youth policy of the Russian Federation for the period up to 2025, it will be strategically important to create conditions for the formation of personality, constantly 
improving, competitive, with moral principles, able to adapt to changing conditions and ready for new creative ideas[7].

As a consequence, the task of youth policy will be the education of patriotic-minded young people with critical, independent thinking, with a creative outlook, professional knowledge, and skills, high culture, including the culture of international communication, responsibility, and the ability to make independent decisions aimed at improving the welfare of the country, the people and their families [7]. The identical task becomes a reference point for educational institutions and should be directly implemented in their work. Particular attention should be paid to the socialization of students in the conditions of transforming social and economic living conditions. We believe that in order to increase the level of personal socialization it is necessary to disseminate the models of successful socialization, development of research, engineering, technical, design activities of students, emphasize the education of specific competencies, qualities, and behavioral practices, primarily in young people, schoolchildren, students in a multicultural and multiconfessional society, to form skills, cognitive, meta-, social-emotional, physical and practical competencies. To a greater extent, the institution of education can meet these challenges. It should be proactive, preparing people for life in an ever-changing world, digitalization of society, contribute to the development of students' potential, their desire to become active, involved participants in life events, to be able to solve social problems, make decisions, and take responsibility for them, that is to contribute to the successful socialization of the individual in general. In this aspect, we consider the statement by K. Marx, who argued that the social reality surrounding the man is both a condition and a consequence of human activity. At the same time, the individual is not passive in terms of socialization, but rather actively participates in this process. In the process of assimilating and using his experience, he is already able to influence his own development and further socialization[6].

The educational environment is one of the fundamental factors influencing the socialization of a personality, which takes into account cultural, educational traditions, forms a personality during education, primarily in an educational institution, where a student spends most of his time. It is a source of learning, education, development of the student, promotes motivation to acquire new knowledge, activities, skills, development of abilities, creates conditions for overcoming difficulties and achieving learning outcomes, forms the resources needed in the learning process. The requirements for the educational environment are constantly transforming, which is determined by the changes taking place in society and the world. The current educational environment is an open self-developing space, represented by various social institutions, including educational institutions and institutions of additional education, culture and sports, network centers, integrated socio-cultural institutions that perform not only the functions of education and upbringing, but also other social functions (culture, sports, leisure), resource centers, network models, social partnership, resource provision (equipment, training simulators, books, reference books, manuals, programs, personnel), virtual environment, individual space, transforming spaces inside the school (students personally choose ways to organize them to achieve specific goals and objectives), experimental spaces, where students also independently choose research projects, form groups and organize their implementation, which in general contributes to the productive assimilation of knowledge, improving their quality, acquiring shared social experience, socialization of students. Let us clarify what we will mean by socialization. "Socialization is a two-way process of, on the one hand, assimilation by a human individual of a certain system of knowledge, norms, and values of society for the purpose of development and self-realization throughout life, and on the other hand, reproduction of culture and social experience, which allows a person to function as a full member of society" (8). 


\section{Research Results}

It is always relevant for society to educate a socialized person, which the situation with Covid-19 in the world has shown very clearly. A person should have certain competencies, which will allow a person to respond adequately to the events taking place in the world, adapt to them and continue to live qualitatively further in the new socio-economic conditions.

Hence, an important milestone in a person's life is the period of his/her professional selfdetermination, i.e. pre-professional socialization, the last stage of his/her schooling, choice of profession, educational trajectory, and forecasting of his/her future life. The modern economy imposes specific requirements on the graduate of an educational institution. The picture of the world is changing and the requirements to participants of the labor market, educational trajectories, acquired competencies also change. We have analyzed the works of many scientists who have dealt with the issue of studying personality competencies. These are A.V. Khutorskoy, I.A. Zimnaya, V.N. Kunitsina, A.I. Subetto, L.I. Bozhovich, D.I. The following competencies and behavioral practices, which will help students to socialize in a changing world, are relevant.

Table 1. Social competencies [9]

\begin{tabular}{|c|c|c|}
\hline $\begin{array}{c}\text { Name of } \\
\text { competence }\end{array}$ & Definition & Behavioral indicators \\
\hline $\begin{array}{l}\text { General } \\
\text { Culture }\end{array}$ & $\begin{array}{l}\text { Willingness to embrace the culture of } \\
\text { different peoples and the diversity of } \\
\text { society and to apply knowledge of } \\
\text { universal culture in life and practice }\end{array}$ & $\begin{array}{l}\text { Erudition, love for nature, purposefulness, } \\
\text { respect for people, responsibility, decency, } \\
\text { politeness, caring, readiness for self- } \\
\text { development, self-actualization, use of } \\
\text { creative potential }\end{array}$ \\
\hline $\begin{array}{l}\text { Values and } \\
\text { attitudes }\end{array}$ & $\begin{array}{l}\text { Ability and aspiration to form an } \\
\text { independent life position based on } \\
\text { socially accepted norms and values }\end{array}$ & $\begin{array}{l}\text { Patriotism, dignity, kindness, duty, } \\
\text { unselfishness, responsibility, } \\
\text { independence, modesty, integrity, } \\
\text { honesty, self-criticism. The search for the } \\
\text { meaning of life, orientation in life values, } \\
\text { the installation of positive life strategies, } \\
\text { the formation and development of } \\
\text { attitudes and beliefs, points of view, } \\
\text { empathy, morality, sincerity }\end{array}$ \\
\hline $\begin{array}{c}\text { Project } \\
\text { Cognitive }\end{array}$ & $\begin{array}{l}\text { Ability to project future life } \\
\text { benchmarks, goals, and objectives, to } \\
\text { determine possible ways of their } \\
\text { solution, including for the } \\
\text { implementation of own projects based } \\
\text { on creative search, self-development, } \\
\text { and lifelong learning, to be able to } \\
\text { reflect the results of the implemented } \\
\text { project, to correct mistakes and to plan } \\
\text { further activities. }\end{array}$ & $\begin{array}{l}\text { Creativity, openness, purposefulness, } \\
\text { creativity, diligence, activity, } \\
\text { attentiveness, learnability, persistence, } \\
\text { initiative, ability to bring the started thing } \\
\text { to the end, intellect, diligence, } \\
\text { independence, purposefulness, } \\
\text { judiciousness, adequacy of self-esteem, } \\
\text { courage, responsibility, initiative, stress- } \\
\text { resistance, communication, creativity }\end{array}$ \\
\hline
\end{tabular}




\begin{tabular}{|c|c|c|}
\hline Name of & Definition & Behavioral indicators \\
\hline $\begin{array}{c}\text { Pre- } \\
\text { professional }\end{array}$ & $\begin{array}{l}\text { Willingness to get a certain profession } \\
\text { in accordance with changes in the } \\
\text { labor market, to be able to build an } \\
\text { optimal educational trajectory, to } \\
\text { learn throughout life, willingness to } \\
\text { reflect on their actions and take care of } \\
\text { their mental and physical health }\end{array}$ & $\begin{array}{l}\text { Hard work, erudition, diligence, } \\
\text { persistence, conscientiousness, } \\
\text { communication skills, punctuality, } \\
\text { determination, responsibility, thriftiness, } \\
\text { discipline, independence, friendliness, } \\
\text { tolerance, obligation }\end{array}$ \\
\hline $\begin{array}{l}\text { Information } \\
\text { and } \\
\text { communicat } \\
\text { ion }\end{array}$ & $\begin{array}{l}\text { Ability to interact socially, work in a } \\
\text { team, find the right information and } \\
\text { apply it effectively in practice, ability } \\
\text { to work in a technologically rich } \\
\text { environment }\end{array}$ & $\begin{array}{l}\text { Attention, respect for people, sociability, } \\
\text { purposefulness benevolence, sensitivity, } \\
\text { responsiveness, tolerance, determination, } \\
\text { literacy. }\end{array}$ \\
\hline $\begin{array}{l}\text { Entrepreneu } \\
\text { rial }\end{array}$ & $\begin{array}{l}\text { Willingness to use knowledge of } \\
\text { financial literacy, marketing, } \\
\text { management, law to organize } \\
\text { planning and solve business and } \\
\text { entrepreneurial issues. }\end{array}$ & $\begin{array}{l}\text { Initiative, adaptability, mobility, } \\
\text { persistence, conscientiousness, } \\
\text { confidence, responsibility, honesty, } \\
\text { independence, communication skills, } \\
\text { stress resistance, purposefulness, } \\
\text { determination, tolerance, obligation to } \\
\text { compromise. }\end{array}$ \\
\hline
\end{tabular}

All proposed groups of competencies contain a socially-oriented orientation, which contributes to the accumulation of knowledge, abilities, skills, and personal characteristics in students. They develop the ability to respond to the challenges of the modern environment, i.e. to develop a socialized person who is able to be useful to society and himself, to integrate into the new socio-economic conditions of life, and to act successfully in the existing realities.

Social competencies are fostered through different social institutions, including the general education system. The introduction of federal state educational standards of a new generation for all levels of education, modern educational technologies, the further development of specialized education in high school, updating the content and methods of teaching in such educational areas of the school as technology, foreign languages, social sciences, the advanced development of mathematical education, the use of distance learning, online learning, artificial intelligence, creating a high-tech environment for teaching in schools (high-speed Internet, new generation digital educational resources such as "I-Class", virtual learning laboratories, educational online platforms), knowledge portals, small universities, educational clusters, small school enterprises - all of this should contribute to the development of social competencies, obtaining primary professional experience, correct professional self-determination, readiness for life in the conditions of society transformation, digital space and the success of the personality of students and sustainable development of society.

In order to socialize students, the content and technologies of vocational education should be changed to ensure their compliance with FSES, employers' requirements, labor market, and digital environment. As a consequence, new social, cultural, technological opportunities will be created for the successful socialization of the individual. The system of continuous education will be further developed to build modular trajectories for mastering new competencies in accordance with the demands of the population, labor market, business entities, professional qualification centers (resource centers). Secondary vocational education programs are being transformed into applied bachelor programs, the interaction of network 
organizations, development of social partnership, internationalization, digitalization of Russian education, and expansion of mobility of Russian educational services continue.

Thus, we see that the state has the necessary conditions and resources for successful socialization of the individual, ready for the changes taking place in the world, able to adapt to new conditions, understanding the need for lifelong learning, receiving education in demand in a particular period and in specific socio-economic conditions, transforming the experience and knowledge gained to perform a certain level of tasks and mastering the competencies demanded in the labor market to realize themselves as a participant of this market, a successful member of society.

We express our gratitude to Amirov Arthur Ferdsovich, Doctor of Pedagogical Sciences, Professor, Head of the Department of Pedagogy and Psychology, Bashkir State Medical University, Ufa, Amirova Lyudmila Aleksandrovna, Doctor of Pedagogical Sciences, Professor, Excellence in Education RB, Bashkir State Pedagogical University named after M. Akmulla, Ufa, Chudinov A.P, Ural State Pedagogical University, Doctor of Pedagogical Sciences, Professor, Head of Chair of Intercultural Communication, Rhetoric and Russian as a Foreign Language, for their valuable advice on planning and conducting the research, the honorable referees for their thorough reading of the article and their recommendations.

\section{References}

1. A.R. Demchenko, M.V. Morozova, Pedagogika 8, 108 (2013)

2. B.M. Bim-Bad, Pedagogical Encyclopedic Dictionary. M., 42 (2002)

3. D. Ortega-Sánchez, I. M. Gómez-Trigueros, Sustainability (Switzerland), 11(3), (2019)

4. D. Quaye, I. Mensah, Management Decision, 57(7), 1535 (2019)

5. Decree of May 7, 2012 No. 597 "On measures for the implementation of state social policy."

6. Decree of May 7, 2012 No. 599 "On measures to implement state policy in the field of education and science"

7. E. Auld, P. Morris, Policy Futures in Education, 17(6), 677 (2019)

8. E. Malchrowicz-Mośko, M. Młodzik, P. León-Guereño, K. Adamczewska, Sustainability (Switzerland), 11(23), (2019)

9. E.F. Zeer, Actual problems of psychological knowledge 3(36), 16 (2015)

10. Federal Law "On Education in the Russian Federation" dated December 29, 2012 No. 273-FZ (Approved by the President of the Russian Federation on December 29, 2012.)

11. Federal target program for the development of education for 2016-2020 (approved by the decree of the Government of the Russian Federation of May 23, 2015 No. 497)

12. Fundamentals of the state youth policy of the Russian Federation for the period up to 2025: Order of the Government of the Russian Federation No. 2403-r: adopted by the Government of the Russian Federation on November 29, 2014. Russian State Library for Youth. http://www.rgub.ru/files/state_policy-1021-2.pdf

13. G.A. Kostetskaya, Young Scientist, 18(1), 49 (2014)

14. G.F. Trubina, Pre-professional socialization of a schoolchild in the learning process: a socio-technological approach: monograph, Kazan (Buk, 2018)

15. G.R. Igtisamova, Bulletin of the Maikop State Technological University, 1, 120 (2012).

16. H. Pham, S. Kim, Sustainable Production and Consumption, 20, 1 (2019)

17. I.M. Kurdyumova, Modernization of general education abroad: a monograph for workers in education and science, (Publishing house of RAO, 2006).

18. K. Marx and F. Engels, From early works: Edition: M. State Publishing House of Political Literature, 699 (1956)

19. M. Capasso, T. Hansen, J. Heiberg, A. Klitkou, M. Steen, Technological Forecasting and Social Change 146, 390 (2019) 
20. National doctrine of education in the Russian Federation (for the period until 2025). http://www.lexed.ru/obrazovatelnoe-pravo/knigi/yagofarov2005/413.php

21. R. Bernal, L. San-Jose, J. L. Retolaza, Sustainability (Switzerland) 11(15), (2019)

22. R. Lozano, M. Barreiro-Gen, F.J. Lozano, K. Sammalisto, Sustainability (Switzerland) 11(6), (2019)

23. S. Semerikov, A. Striuk, L. Striuk, M. Striuk, H. Shalatska, E3S Web of Conferences, (2020)

24. V. A. Slastenin, I. F. Isaev, E. N. Shiyanov, Pedagogy, (Publishing Center "Academy", 2013)

25. W. Lambrechts, C. J. Gelderman, J. Semeijn, E. Verhoeven, Journal of Cleaner Production, 208, 1631 (2019) 